\title{
SOME AVIAN TAPEWORMS FROM ANTIGUA
}

\author{
BY JEAN G. BAER \\ Neuchâtel
}

(With 37 Figures in the Text)

THE small collection of avian tapeworms from Antigua which is the subject of the present paper was sent to us for identification, through Prof. R. T. Leiper, by Mr L. R. Hutson, Veterinary Officer, Antigua, to whom we tender our sincerest thanks.

Although one species only was found to be new to science, the collection contained several interesting specimens of lesser known genera from Charadriiform birds and from grebes. As most of these species have never been found again since their description, we have been able to complete the original descriptions and compare our specimens with nearly all the actual types deposited in Prof. Fuhrmann's collection. Several systematic modifications have resulted from this study and will be discussed later. We are most grateful to Prof. Fuhrmann for the loan of these types.

The genus Hymenolepis is represented by four species, one of which is new.

\section{Hymenolepis flagellata Fuhrmann, 1906}

Two incomplete specimens were collected from a Bahama duck, Poecilonetta bahamensis (L.); the scolex is missing in both cases. We have, however, been able to base our identification on the internal anatomy which is sufficiently characteristic, and also on the fact that it was recorded from the type host.

\section{Hymenolepis lobulata Mayhew, 1925}

Several species from a pied-billed grebe, Podilymbus podiceps (L.) agree with Mayhew's (1925) description. None of our specimens had a completely everted rostellum so that we are unable to confirm the peculiar arrangement of the hooks. The scolex is $560-576 \mu$ in diameter and each sucker measures $240-280 \mu$. The total length of the partially everted rostellum is nearly $400 \mu$ and the diameter only $36 \mu$. All our specimens show ten hooks only. According to Mayhew (1925, p. 43) their number varies from eight to eleven. These hooks are $15-16 \mu$ long and $17 \mu$ at the base; their shape as indicated by Mayhew (Pl. IV, fig. 35) does not give a correct idea of the structure of the base which is very much flattened, triangular with slightly raised edges (Fig. 1). We have drawn several hooks under different angles in order to bring out the variation of the shape under these conditions. The internal anatomy agrees with the original description, except that the longitudinal musculature is arranged in two definite layers of bundles, the bundles of the inner layer being larger than 
those of the outer, as is the case in most of the species of this genus (Fig. 2). The uterus passes laterally beyond the longitudinal excretory vessels; it was devoid of ripe ova.

\section{Hymenolepis himantopodis (Krabbe, 1869)}

Only two specimens from a Black-necked Stilt, Himantopus mexicanus Müll., were found. This species is easily recognized by the very small size of the rostellar hooks $(8 \mu)$, as well as by their shape. The above host is not new for this species.
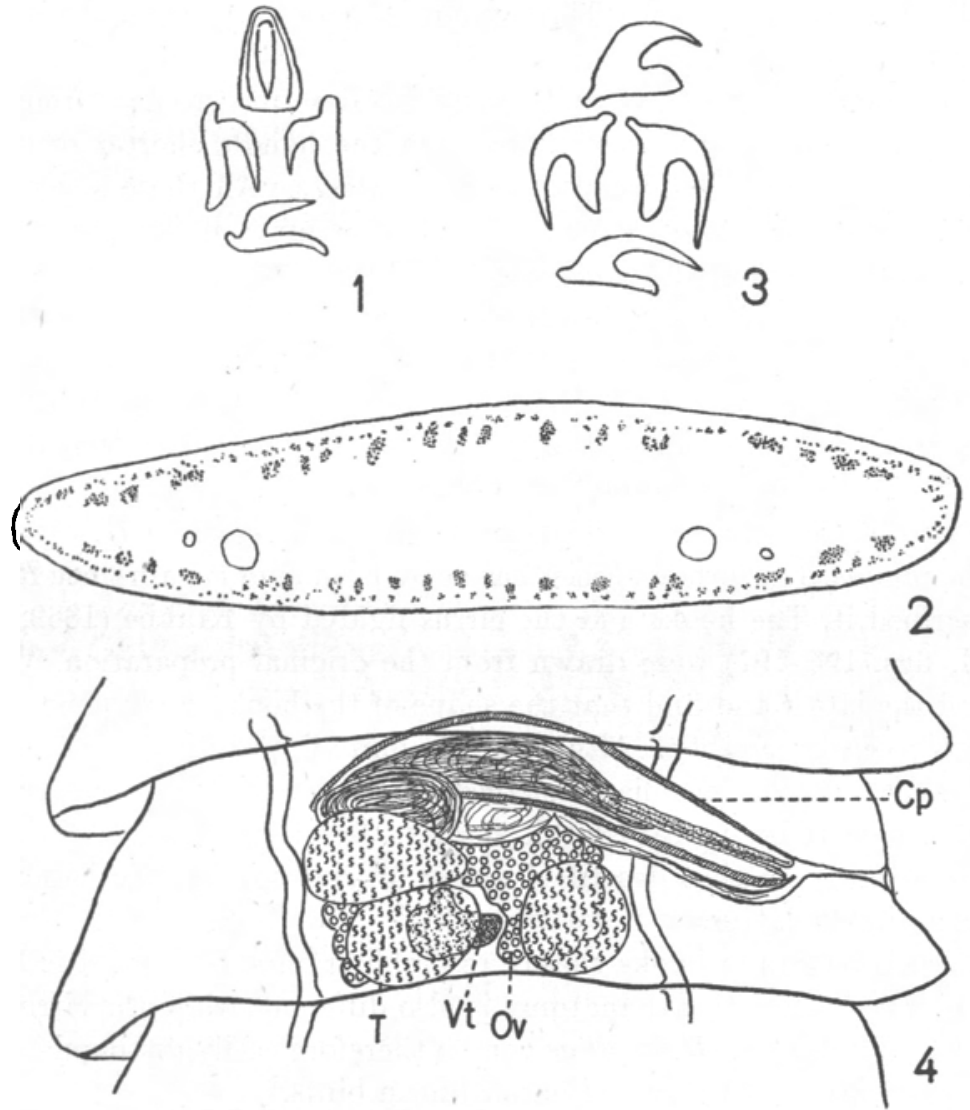

Figs. 1-4. 1. Hymenolepis lobulata Mayhew, rostellar hooks. 2. Transverse section of same to show the longitudinal muscles. 3. Hymenolepis capellae n.sp. rostellar hooks. 4. Adult segment: $C p$, oirrus pouch; $O v$, ovary; $T$, testes; $\nabla t$, yolk gland.

\section{Hymenolepis capellae n.sp.}

This new species was recovered from a Wilson's snipe, Capella delicata (Ord.). The total length is about $30 \mathrm{~mm}$. and the maximum width $1 \mathrm{~mm}$. in contracted specimens. The scolex.measures $216 \mu$ in diameter and the suckers 72-100 $\mu$. The rostellum is $144 \mu$ in length and only $61 \mu$ in diameter; it bears 
ten hooks of a peculiar shape 18-21 $\mu$ long with a base measuring $15 \mu$ (Fig. 3). These hooks resemble those generally found in the genus Haploparaxis; the handle is extremely short and the blade is longer than the guard.

The three testes are large, $72 \mu$ in diameter, and are grouped so as to form a triangle (Fig. 4). The cirrus pouch is long and reaches almost to the anti-poral excretory vessels. It is $234-252 \mu$ long and $36 \mu$ in diameter. The cirrus is densely covered with very fine spines. The female glands are situated medially and there is a very large receptaculum seminis as in most species of this genus. The gravid uterus completely fills the segments passing laterally beyond the longitudinal excretory vessels. The ova are $35 \mu$ in diameter and contain an embryo $(23 \mu)$.

Of the twenty-eight species of Hymenolepis described to date from Charadriiform birds, only seven have hooks with the handle shorter or equal to the guard, i.e. hooks of the type described above. All these seven species possess ten hooks the measurements of which are given in brackets following the name of the species: $H$. annandale $i$ Southwell, $1922(32 \mu) ; H$. annandalei longosacco Joyeux \& Baer, $1939(27-30 \mu)$; H. amphitricha (Rudolphi, 1819) $(20-23 \mu)$; H. chionis Fuhrmann, $1921(21 \cdot 6-23 \mu)$; H. clandestina (Krabbe, 1869) $(47 \mu)$; H. recurvirostrae (Krabbe, 1869) (13-17 $\mu$; H. recurvirostrae magnosacco Joyeux \& Baer, 1936; $H$. recurvirostroides Meggitt, 1927 (10-15 $\mu$ ); H. uliginosa (Krabbe, 1882) (42-45 $\mu)$.

The size of the hooks of our species brings it nearest to $H$. amphitricha and to H. chionis. The former species has never been found again since Rudolphi first described it. The hooks and the cirrus figured by Krabbe (1869, p. 311, pl. VIII, figs. 195-197) were drawn from the original preparation. We have examined the latter and find that the shape of the hooks corresponds exactly with that given by Krabbe. Although it is quite impossible to make out the internal anatomy, the peculiarly shaped spines on the cirrus can be easily seen and appear to be typical for this species. Besides, the shape of the hooks is also different from that described above for our species, the handle being longer than in the latter.

H. chionis bears ten hooks closely resembling ours, the guard is however much wider and the internal anatomy is also different, while the cirrus pouch is considerably shorter. H. capellae can be therefore easily distinguished from the other species recorded from Charadriiform birds.

\section{Acoleus vaginatus (Rudolphi, 1819)}

A single specimen was collected from the gut of a black-necked stilt, Himantopus mexicanus Müll. As a well-preserved scolex was present, we can assert the complete absence of rostellar hooks. This scolex measures $640 \mu$ in diameter and the suckers $280-400 \mu$ each in length by $120 \mu$ in width. Their opening is situated near the apex of the scolex. The rostellum is ovoid, measuring $320 \times 240 \mu$; it appears to contain deeply staining, most probably glandular. cells (Fig. 5). The internal anatomy is very typical and has been largely worked 
out by Fuhrmann (1899). The longitudinal muscles are disposed in two distinct layers separated by transverse muscles (Fig. 6). The testes are numerous, about 130 , in two layers. They do not form two groups as originally stated (Fuhrmann, 1899, p. 347), but occupy the whole dorsal field in the anterior half of the proglottid (Fig. 7). The cirrus is armed with small hooks $28-35 \mu$ long, slightly curved (Fig. 8). We have been able to compare our specimens with Rudolphi's original types and find the shape of these hooklets to be identical in the two specimens.

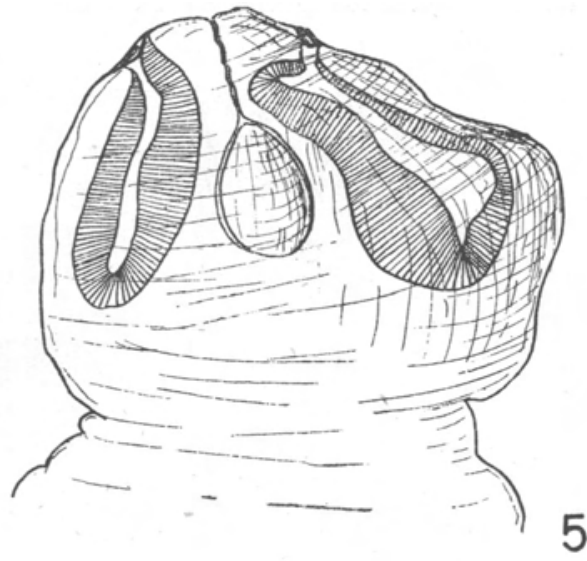
No eggs were present, as completely ripe segments are missing.

Three species of the genus Acoleus have been described to date from Charadriiform birds; these are: $A$. crassus Fuhrmann, $1900 ; A$. hedleyi Johnston, 1910; $A$. vaginatus (Rudolphi, 1819).

$A$. hedleyi, as described by Johnston (1912, p. 23), differs from $A$. vaginatus in being slightly smaller than the latter species, moreover, the testes are distributed in a single field and the shape of the hooklets of the cirrus is almost the same, so that we do not think it necessary to retain this species

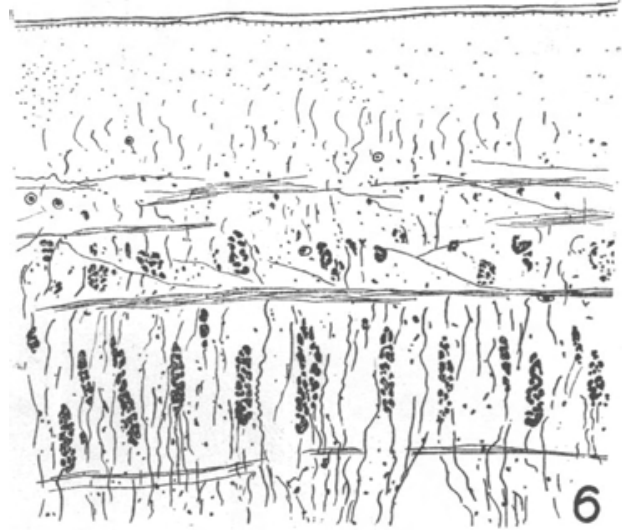

Figs. 5, 6. 5. Acoleus vaginatus (Rud.), scolex. 6. Portion of a transverse section of this species showing the longitudinal musculature.

as distinct from $A$. vaginatus. Besides, the hosts belong to the same genus, since $A$. hedleyi comes from Himantopus leucocephalus Gould.
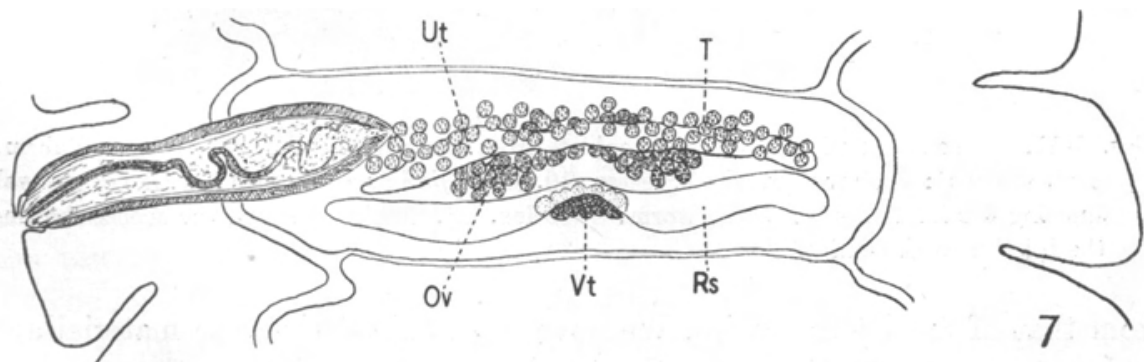

Fig. 7. Acoleus vaginatus (Rud.), adult segment: $O v$, ovary; $R s$, receptaculum seminis; $T$, testes; $U t$, uterus; $V t$, yolk gland. 
Acoleus crassus from a Brazilian Tringa sp. was originally separated from Acoleus vaginatus because of its internal anatomy which differs considerably

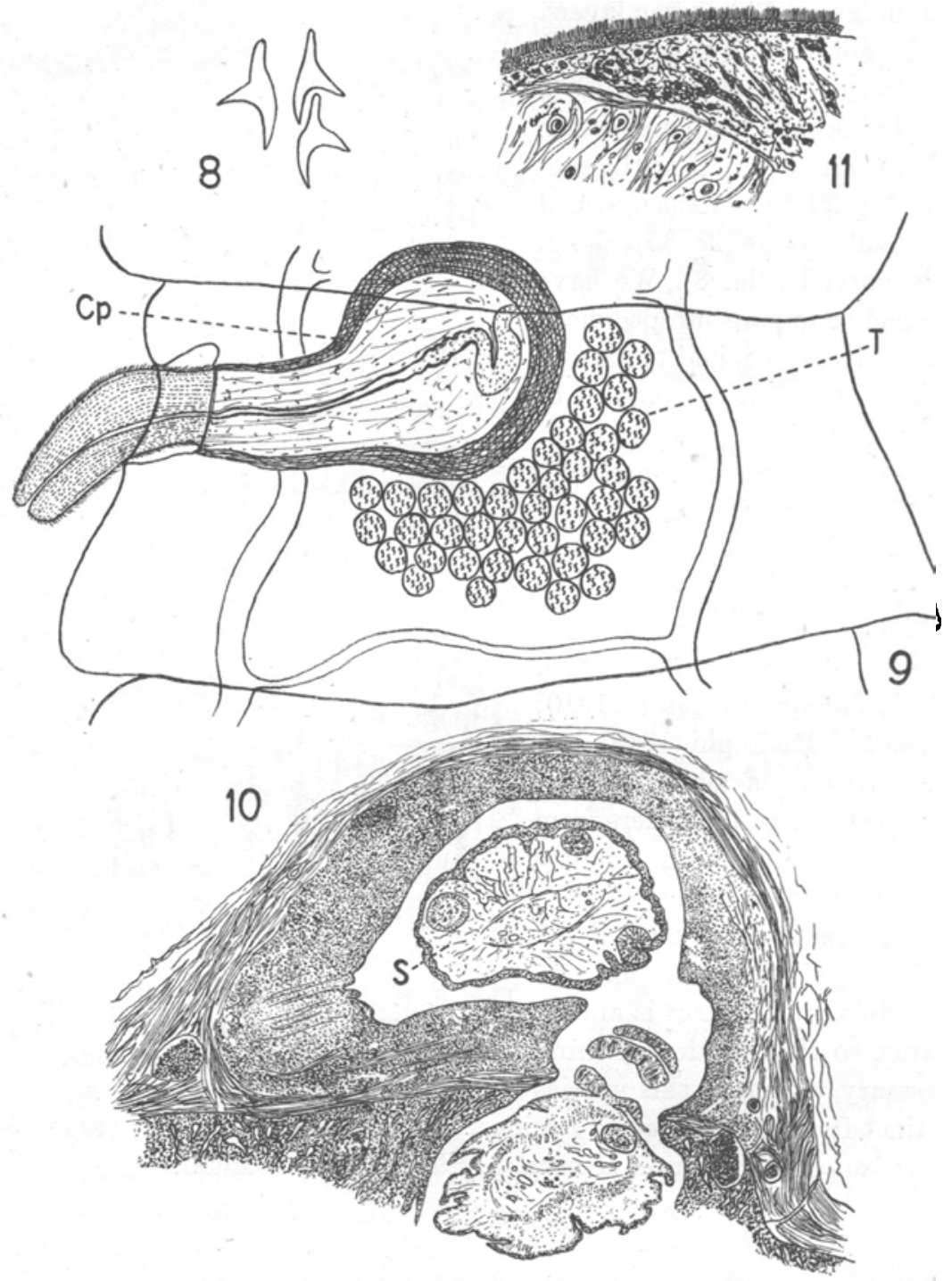

Figs. 8-11. 8. Acoleus vaginatus (Rud.), hooklets from the cirrus. 9. Acoleus crassus Fuhrm., adult segment: $C p$, cirrus pouch; $T$, testes. 10. Shipleyia inermis Fuhrm., section of gut-wall showing the implantation of the worm: $S$, scolex. 11. Section through the scolex showing the bristles on the cuticula.

from that of the latter species. We have re-examined the type material and find on transverse sections that the cirrus pouch passes between the excretory vessels and not ventrally to the latter as in $A$. vaginatus. On the other hand, 
the structure of the cirrus pouch is totally different from that of $A$. vaginatus (Fig. 9). The number and arrangement of the testes is also different. The female genitalia can no longer be made out on these preparations over a hundred years old. The scolex is $464 \mu$ in diameter and the four circular suckers $216-220 \mu$. An everted rostellum $240 \times 56 \mu$ has lost its hooks. The cirrus pouch is $480-560 \mu$ long and $240 \mu$ in diameter at its base, which is almost spherical.

The above characters, together with those given in the original description, have convinced us that this species must be removed from the genus Acoleus to the genus Gyrocoelia. On comparing this species with the types of $G$. leuce Fuhrmann, 1900, we find the two species to be identical; besides, both are found in South American Charadriiform birds. We will discuss the status of the genus Gyrocoelia in another part of this paper, but can already clarify the question of the nomenclature. A. crassus and $G$. leuce were both described as new species in the same paper (Fuhrmann, 1900, pp. 370, 371). The specific name crassus has page precedence over the name leuce, therefore Gyrocoelia leuce Fubrmann, 1900 must now be named Gyrocoelia crassa (Fuhrmann, 1900), syn. Acoleus crassus Fuhrmann, 1900.

Acoleus longispiculus (Stossich, 1895) described originally as a Bothriocephalus from a water hen, Zapornia parva (Scop.), appears from the structure of the scolex and of the eggs, to be identical with Acoleus vaginatus. For the time being, however, and until fresh material has been examined from the same host, we prefer to consider this species as distinct.

\section{Shipleyia inermis Fuhrmann, 1908}

Several specimens were obtained from a Wilson's snipe, Capella delicata (Ord.). As our material is very well preserved, we have been able to make a complete study of this interesting species, and to compare our specimens with the original types which are however very badly preserved.

The scolex and the anterior part of the strobila are deeply embedded in the intestinal wall of the host, passing right through the muscularis mucosae into the external muscle layer of the gut (Fig. 10). This peculiar implantation of the worm resembles somewhat that already described for the species Parorchites zederi (Baird, 1853) and Paradilepis macracantha Joyeux \& Baer, 1935. In this case, however, the tissues of the host show a distinct necrosis resulting in a considerable destruction of tissues. The scolex, although unarmed, is covered with dense cuticular spines, almost resembling fine bristles (Fig. 11). These latter, through the continual motion of the scolex, must set up an inflammatory process which results in the above destruction of the tissues. On sections of the type material, we have found an identical implantation in the host.

The longitudinal musculature is very well developed and consists of two layers of rather large bundles, each containing numerous fibres with very prominent myoblasts (Fig. 12). The longitudinal bundles, the largest of which are the innermost, are separated from one another by transverse fibres. 
The longitudinal excretory vessels are situated ventrally and dorsally, the dorsal vessels being slightly lateral to the ventral vessels. In each proglottid both the dorsal and the ventral vessels are united by transverse vessels, the latter always passing dorsally to the female genitalia (Fig. 13). We have found the same arrangement in all the genera of Acoloeidae examined. The flame cells are very distinct and extremely numerous, especially in the immediate vicinity of the dorsal vessel where they can easily be seen (Fig. 14).

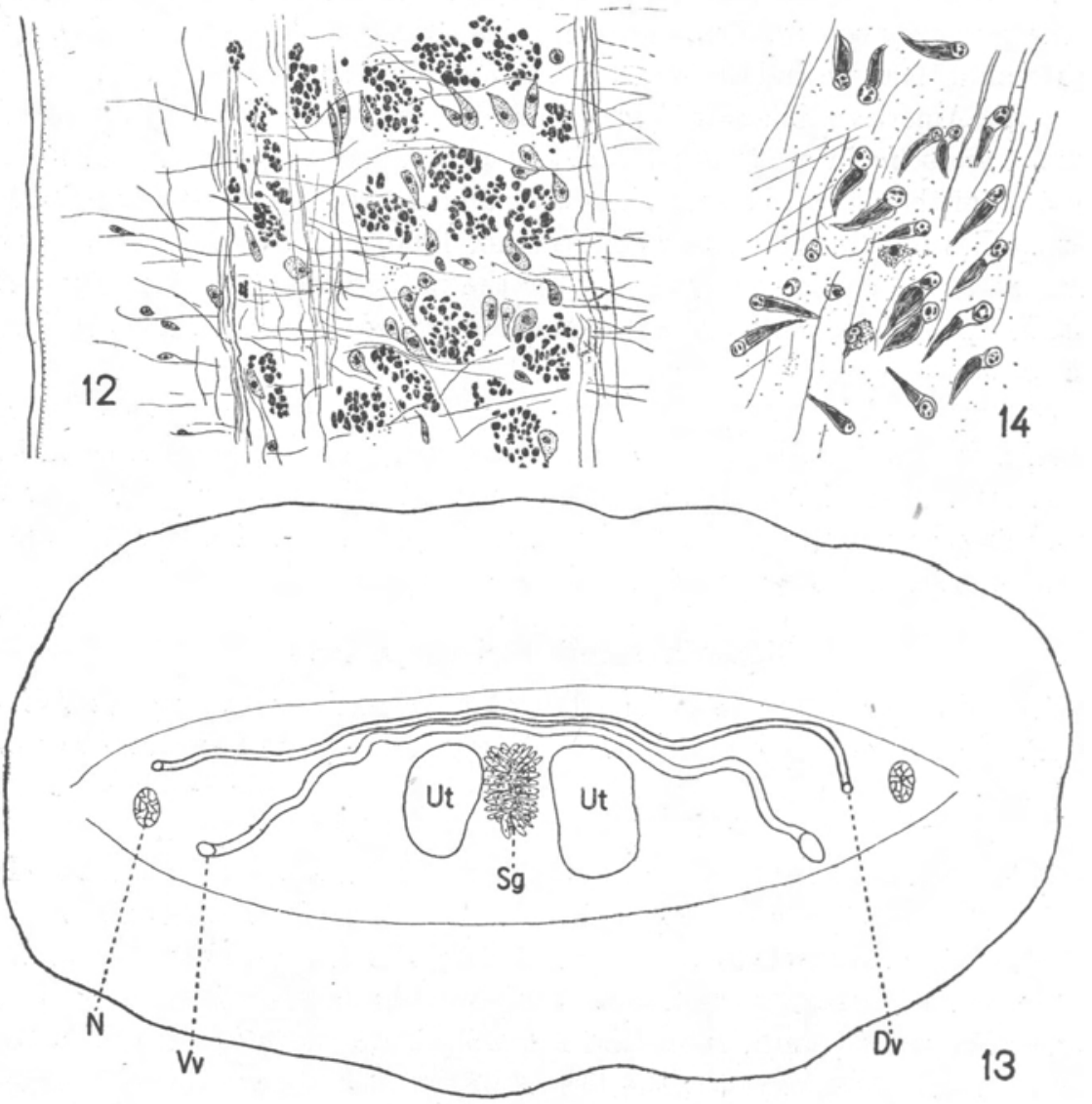

Figs. 12-14. Shipleyia inermis Fuhrm. 12. Portion of a transverse section showing the longitudina musculature. 13. Diagrammatic cross-section showing the relation of the transverse excretory vessels to the genitalia: $D v$, dorsal vessel; $N$, nerve; $S g$, shell gland; $U t$, uterus; $V v$, ventral vessel. 14. Excretory flame-cells from a section.

The internal anatomy of this worm is peculiar in many ways and especially in that the anterior part of the strobila which is entirely male, no female glands being visible although the uterus and receptaculum seminis are present.

The cirrus pouch is large and passes between the longitudinal excretory vessels and dorsally to the nerve (Fig. 15). It is $680 \mu$ long when the cirrus is retracted and has a diameter of $240 \mu$. Its wall is $18 \mu$ thick, consisting of 
longitudinal and oblique muscle fibres. The vas deferens on entering the cirrus pouch dilates to form a small seminal vesicle contained at the base of the cirrus pouch (Fig. 15). The vesicula seminis opens into a well-developed pars prostatica occupying more than half of the cirrus pouch. The cirrus itself is very powerful, $72 \mu$ in diameter, and its entire surface is beset with minute spines which are replaced by real hooklets $21-25 \mu$ long around the base of the cirrus (Fig. 16). These hooklets are deeply implanted into the cuticula of
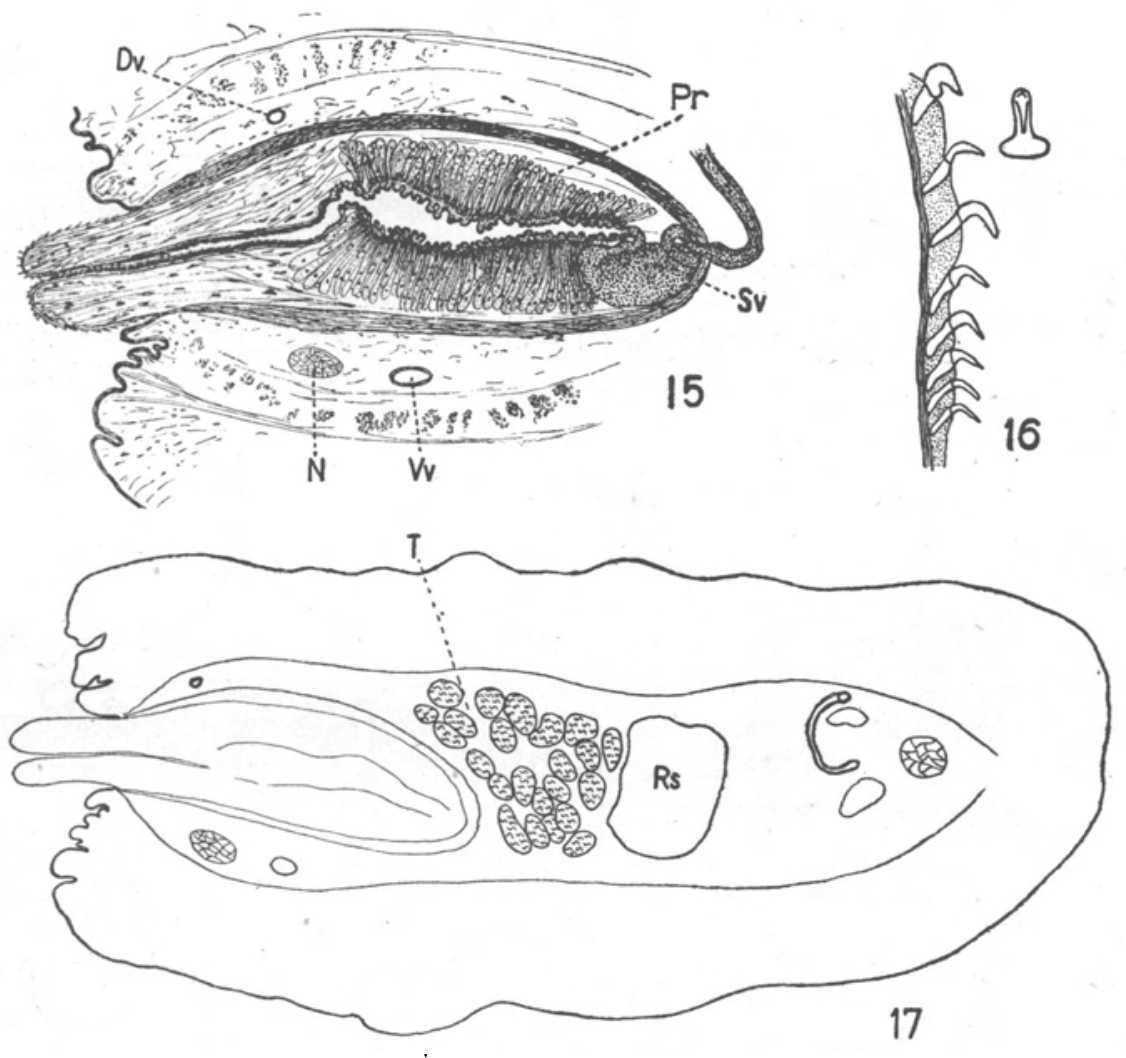

Figs. 15-17. Shipleyia inermis Fuhrm. 15. Cirrus pouch reconstructed from sections: $D v$, dorsal vessel; $N$, nerve; $P r$, prostata; $S v$, seminal vesicle; $V v$, ventral vessel. 16 . Hooklets from the cirrus. 17. Transverse section of a male segment: $R s$, receptaculum seminis; $T$, testes.

the cirrus and are provided with a basal plate which broadens out near the distal end. The fully everted cirrus is $500 \mu$ long and the powerful walls of the cirrus pouch are then $40-48 \mu$ thick. The length of the pouch under these conditions is reduced to $360 \mu$ whereas the diameter is $280 \mu$. There are $20-25$ testes closely packed near the medial end of the cirrus pouch. They can best be seen on transverse sections (Fig. 17) as most of them are situated in a dorso-ventral plane, wedged in between the cirrus pouch and the receptaculum seminis. 
The testes have completely disappeared in the segments in which the female genitalia are formed. The latter differ somewhat from the original description, but we have been able to compare our material with the types and find them both identical. The ovary and the yolk gland are situated symmetrically in the middle of the segment. The ovary is large, compact near the centre, the two lateral wings ending in digitiform processes. It is situated ventrally in the segment. The yolk gland is somewhat dumb-bell-
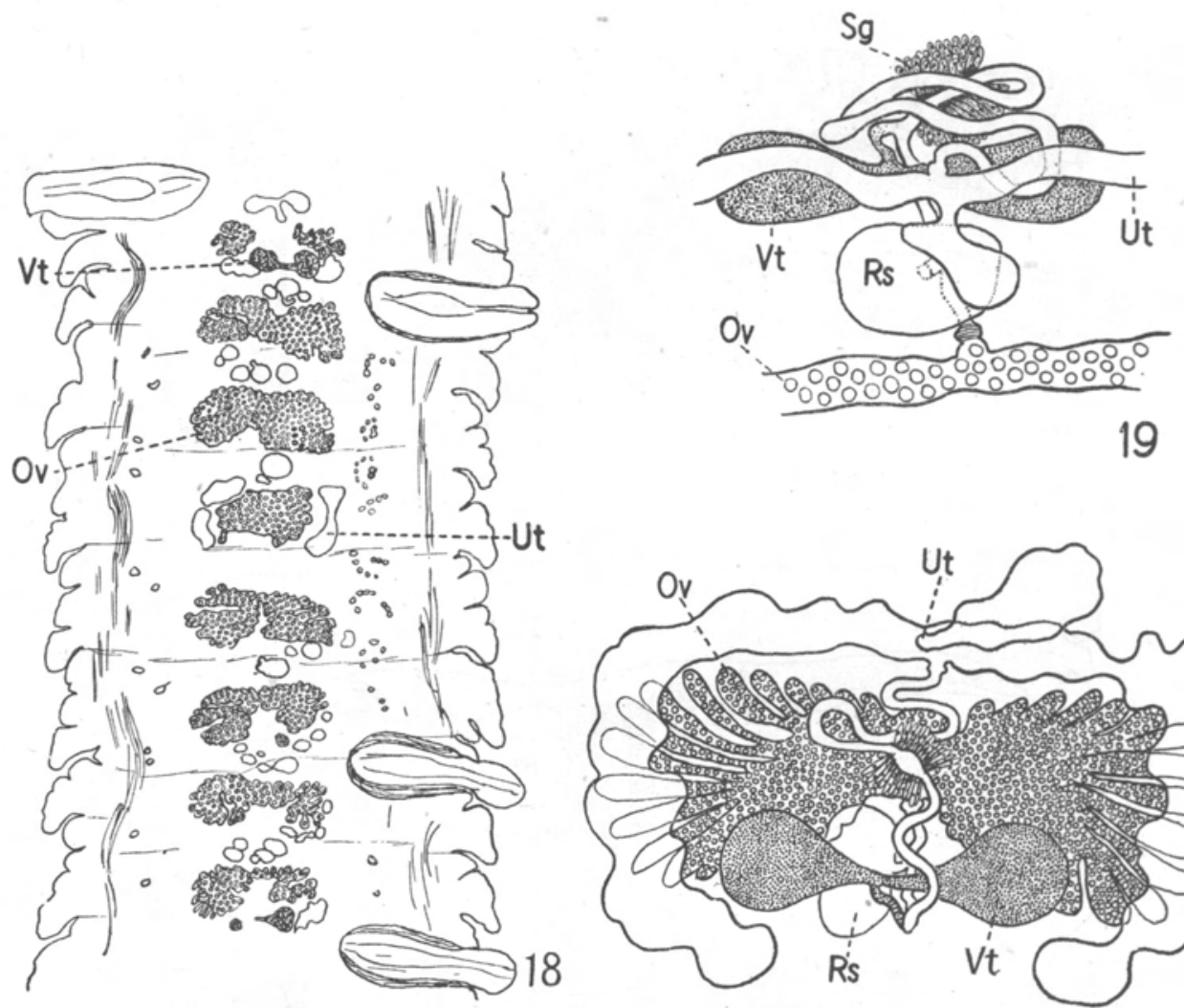

19

Fig. 18. Shipleyia inermis Fuhrm. Horizontal section passing through several segments: $O v$, ovary; $U t$, uterus; $V t$, yolk gland.

Figs. 19, 20. Shipleyia inermis Fuhrm. Diagrammatic reconstruction of the female genitalia. 19. Transverse section. 20. Horizontal section: $O v$, ovary; $R s$, receptaculum seminis; $S g$, shell gland; $U t$, uterus; $V t$, yolk gland.

shaped, and lies on the dorsal surface of the ovary (Figs. 19, 20). The yolk duct arises from the narrow bridge which unites the two lateral halves of the gland, and joins the oviduct. The latter arises from the centre of the ovary, from a very muscular oocapt. The oviduct communicates with a large receptaculum seminis by a short duct. On issuing from the shell gland, the uterine duct enters the uterus at its apex. The uterus is horseshoe-shaped, the two branches being directed postero-laterally, enclosing the female genitalia. Near 
the point where the uterine duct enters the uterus, there is always a large diverticulum of the uterine wall which is directed dorso-ventrally. As the ova collect in the uterus, the walls of the latter bulge out into numerous outpocketings which first appear on the medial and lateral surfaces of the uterus. In gravid segments, the uterus completely fills the segment, all trace of the female genitalia having disappeared. The ripe ova are spindle-shaped and are $51-57 \times 30-32 \mu$. The embryos are $25 \mu$ in diameter.

The study of fresh material makes it necessary to give a more complete diagnosis of the genus Shipleyia Fuhrmann, 1908. This will be as follows:

Acoleidae with a large scolex devoid of a rostellum and hooks. Vagina absent. Male genital pores alternating regularly, the cirrus pouch passing between the longitudinal excretory vessels and dorsally to the nerve. Testes fairly numerous in several dorso-ventral layers, and nearly all situated in the poral half of the segment. Female genitalia median. Ovary and yolk gland symmetrical, the latter postero-dorsal to the ovary. A large receptaculum seminis is present. Uterus horseshoe-shaped with the branches directed backwards, enclosing the female genitalia, and presenting an anterior diverticulum. Later, in gravid segments the uterus fills the entire segment. Ova spindleshaped. Adult in Charadriiform birds.

Type species: Shipleyia inermis Fuhrmann, 1908.

\section{Gyrocoelia milligani Linton, 1927}

Three specimens of this species were collected from a rufous-naped plover, Oxyechus vociferus (L.). We refer our specimens to the above species for reasons given below. The total length is about $40 \mathrm{~mm}$. with a maximum width of $3 \mathrm{~mm}$. The scolex is $400 \mu$ in diameter and each of the suckers measures $184 \times 92 \mu$. The rostellum is $230 \times 69 \mu$; it bears forty hooks arranged in a zigzag, as in all the other members of this genus. The hooks are $32-35 \mu$ long, the guard being hardly set off from the handle, as is usual for this genus.

The longitudinal musculature is well developed, showing the usual two powerful layers of longitudinal bundles separated by transverse fibres (Fig. 21). The cirrus pouch is large, and in young segments $800 \mu$ wide, reaches the anti-poral longitudinal excretory vessels. It passes between the longitudinal vessels and dorsally to the nerve. In these segments, the cirrus pouch is $400-480 \mu$ long and $160 \mu$ in diameter. It contains a very powerful cirrus which, when fully everted, is $480 \times 120 \mu$. Its surface is heavily armed with spines and with hooklets, the latter especially around the base of the cirrus. The wall of the cirrus pouch is $88 \mu$ thick. In mature segments, the cirrus pouch is $640 \mu$ long with a diameter of $160 \mu$. The anatomy of the male genitalia can be clearly seen in Figs. 22-23. There are 14-20 testes each $46-67 \mu$ in diameter. Only very few segments show fully developed testes. The latter disappear very suddenly before the female genitalia are completely developed. We have even found an entirely female strobila with a normal cirrus pouch (Fig. 24). These observations are completed by those of Clausen (1915) and of Tseng Shen 


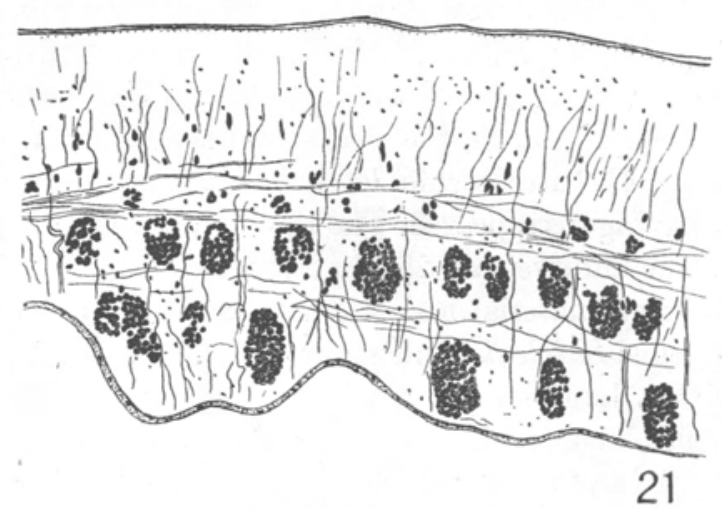

Fig. 21. Gyrocoelia milligani Linton. Portion of a transverse section showing the longitudinal muscles.
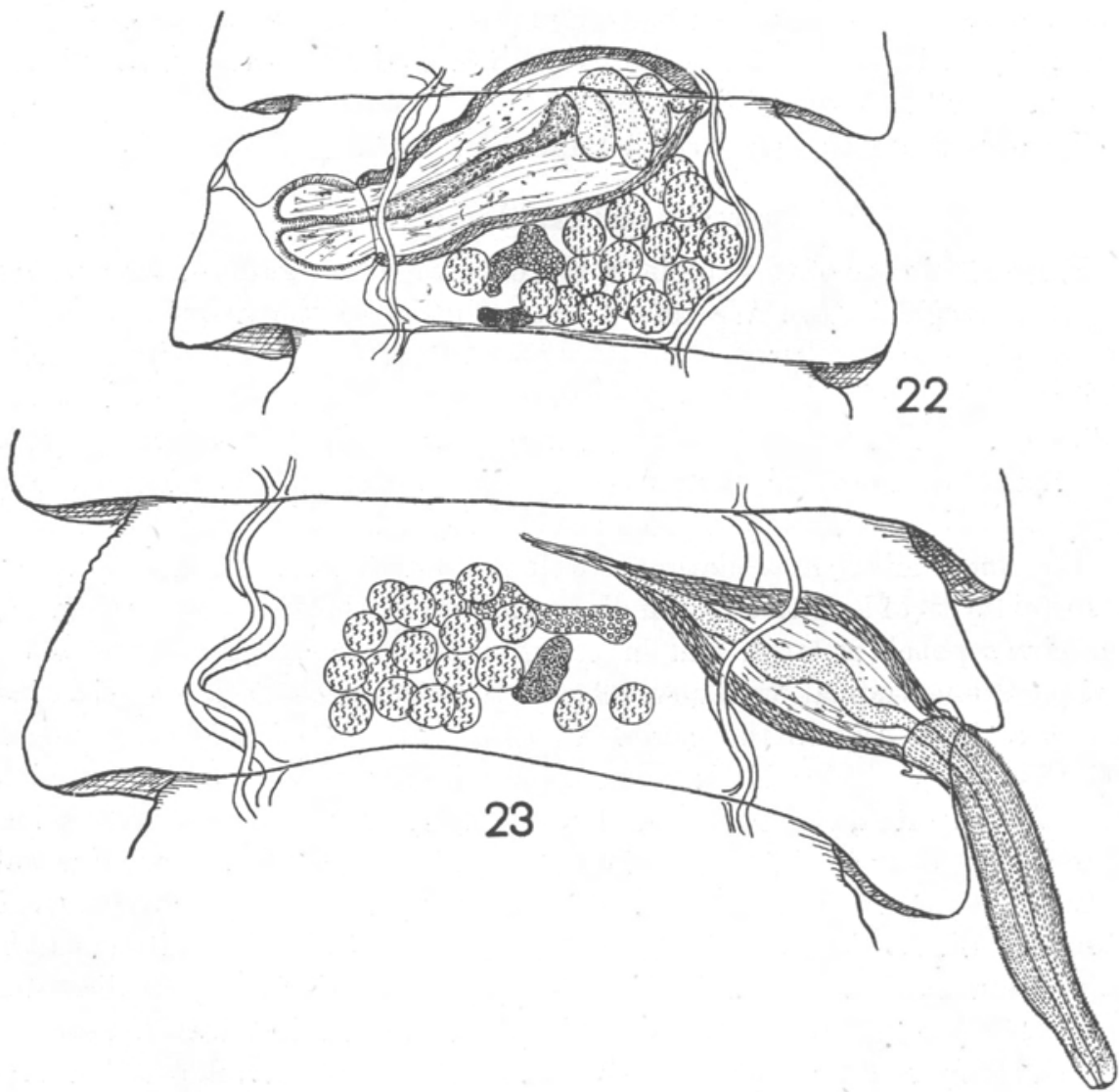

Figs. 22, 23. Gyrocoelia milligani Linton. Two segments of the same strobila showing the fully developed male glands. 
(1933) for other species of the genus Gyrocoelia. The female genitalia occupy the centre of the proglottid and there is a very distinct bilobed receptaculum seminis. The uterus appears as a ring lying ventrally to the female glands without enclosing the latter as in other species (Fig. 25). In gravid segments it is much distended with very numerous outpocketings as in the other species. We have been unable to discover in our material definite dorsal and ventral uterine openings, as found in most species. It is however possible that these only make their appearance in detached gravid segments. On transverse sections of the end proglottids, we find a fibro-cellular parenchyma at the place where this canal ought to be, but although this tissue extends right
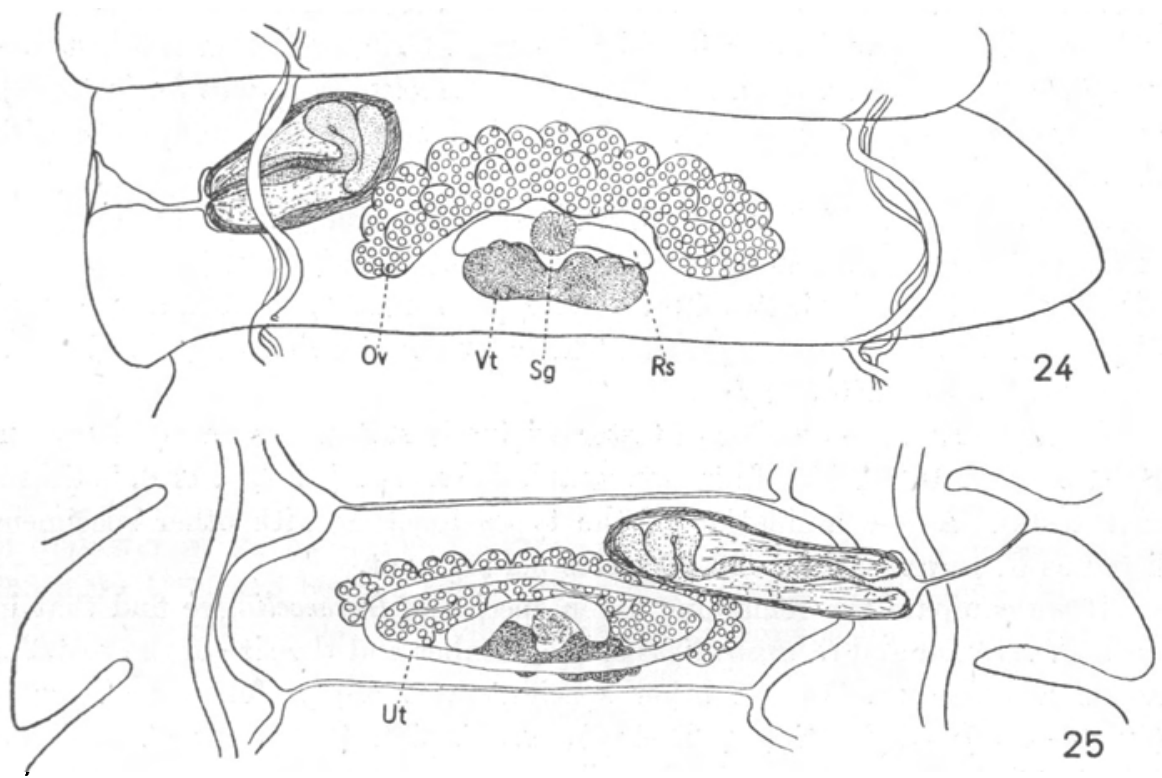

Figs. 24, 25. Gyrocoelia milligani Linton. 24. Female segment in which the testes have completely disappeared. 25. Mature female segment: $O v$, ovary; $R s$, receptaculum seminis; $S g$, shell gland; $U t$, uterus; $V t$, yolk gland.

through the segment, from the dorsal to the ventral surface, a definite canal is not to be found. The ova are spindle-shaped $53 \times 23 \mu$ and the enclosed embryo measures $25 \times 20 \mu$.

G. milligani was placed by Fuhrmann (1932) in the genus Progynotaenia, no doubt on account of its small size. In this latter genus, however, the cirrus pouch lies dorsally to the longitudinal excretory vessels and does not pass in between the latter as in Gyrocoelia. This latter character is emphasized by Linton (1927) in his original description. Although this description is most inadequate, we refer our species to that of Linton's on account of the size of the cirrus pouch and the small number of testes.

The genus Gyrocoelia actually contains eight species, viz.: G. australiensis Johnston, 1912; G. brevis Fuhrmann, 1900; G. crassa (Fuhrmann, 1900); 
G. fausti Tseng Shen, 1933; G. kiewietti Ortlepp, 1937; G. milligani Linton, 1927; G. paradoxa (v. Linstow, 1906); G. perversa Fuhrmann, 1899.

On re-examining the types of $G$. brevis and $G$. leuce $=G$. crassa, we have come to the conclusion that these two species are identical. Skrjabin (1914, p. 82) has already drawn attention to the very close relationship of these two species, of which scolex, hooks and internal anatomy are identical. The only difference, according to Fuhrmann (1900, p. 372), is in the size of the spines of the cirrus, $27 \mu$ in $G$. leuce and $12 \mu$ in G. brevis. We find $14 \mu$ for the former species and 9-12 $\mu$ for the latter and do not feel justified in separating the species on these grounds. It is true that Fuhrmann (1900, p. 373) emphasizes the fact that G. leuce is from a South American host and G. brevis from an African host. There are however other cases in which Charadriiform birds from different continents have the same species of tapeworms (Acoleus vaginatus for instance). In view of these facts we consider Gyrocoelia brevis to be synonymous with G. crassa.

On examining the types of $G$. faust $i$ Tseng Shen, 1933, we find the number of testes to be somewhat larger than stated by Tseng Shen (1933, p. 508). Whereas the latter indicates $42-48$ testes per segment, we find as many as fifty-five testes in several segments. The length of the cirrus pouch, given as $629 \mu$, varies from 440 to $720 \mu$.

In $G$. perversa the number of testes originally stated was four (Fuhrmann, 1899, p. 619). In fig. 140 of his monograph Fuhrmann (1932, p. 170), indicates nine testes. A re-examination of the types together with other specimens listed as $G$. perverse, shows 20-30 testes per segment.

If we compare the remaining seven species of Gyrocoelia we find that in both $G$. perversa and G. australiensis, the number and the size of the rostellar hooks is unknown.- In the other species, these are as follows: $G$. crassa $(40,33-36 \mu)$; G. fausti $(60,21-48 \mu)$; G. kiewietti $(84,29 \mu)$; G. milligani $(40,32-35 \mu) ; G$. paradoxa $(78,29 \mu)$. The number, size and shape of the hooks of $G$. milligani and $G$. crassa are identical. The total length of the worms is about the same, $25-70 \mathrm{~mm}$. for the latter and $24-40 \mathrm{~mm}$. for the former species. The cirrus pouch in $G$. milligani is $450-640 \mu$ long and there are 14-20 testes, whereas in $G$. crassa the cirrus pouch measures $480-1000 \mu$ and the number of testes is 40-45. A study of well-preserved material may perhaps show that these two species are identical, or only subspecies. For the time being, however, it is better to consider them as distinct.

Of the three species with more than forty hooks, G. paradoxa is well established by the length of the cirrus pouch $(320-400 \mu)$ and the small number of testes (14-20). The number of testes in G. kiewietti is not known and it is quite possible that Ortlepp (1937) only had a female strobila. The cirrus pouch is very large $(750 \mu)$, much larger than that of $G$. paradoxa. The rostellar hooks are, however, of the same size $(29 \mu)$ and their number is almost the same (78-84). In this case also, it will be necessary to study more material in order to decide the validity of the species G. kiewietti. 
G. fausti, by the number of the testes and the size of the cirrus pouch appears to be closely related to G. australiensis as redescribed by Maplestone \& Southwell (1922): As, however, the hooks are missing in the latter species, we prefer to consider them as separate species pending further observations.

G. perverse, in which the hooks are also missing, has a very large cirrus pouch $(750 \mu)$ and a few testes $(20-30)$ and its specific identity must remain doubtful for the time being.

We feel almost certain that when more material will have been studied, only two distinct species will probably remain, with perhaps a few subspecies. This is an illustration of the chaos which may result from the description of badly preserved or incomplete specimens.

The removal of G. milligani from the genus Progynotaenia where it had been placed by Fuhrmann (vide supra), has led us to examine more closely the present status of this genus.

The rostellar hooks in Progynotaenia are arranged in a single crown except $P$. evaginata where they are disposed as in Gyrocoelia. An examination of the type specimen of this species has revealed that there are two scolices, the one which no doubt belongs to the genus Gyrocoelia, and another, which presents the typical aspect of the genus Progynotaenia, moreover, the latter is attached to segments showing the anatomy so that no doubt is possible that we are dealing with a species belonging to this genus, whereas the other scolex is a fragment from another worm probably from the same host. The real scolex of $P$. evaginata (Fig. 26) is almost conical and measures $328-336 \mu$ in diameter at its base. The suckers are $180-220 \times 144 \mu$. The rostellum is $288-360 \times 126 \mu$ and bears a single crown of 18 hooks 55-60 $\mu$ long (Fig. 27). With regard to the scolex originally described for this species, we are unwilling to ascribe it to a known species of Gyrocoelia as we know nothing of the internal anatomy of the worm. It corresponds, however, very closely to that of $G$. fausti (vide supra) the size, number and shape of the hooks being the same.

In view of this discovery we have re-examined the types of Progynotaenia pauciannulata Baczynska, 1914 and find that these contain two distinct species, $P$. odhneri Nybelin, 1914 and $P$. evaginata Fuhrmann, 1909. This species is therefore a composite one and must be removed as such from helminthological literature.

$P$. foetida Meggitt, 1928, is without doubt identical with $P$. odhneri, the size and shape of the hooks being the same and the measurements of the genital organs falling within the limits of variability of $P$. odhneri which are much greater than could be supposed as we have been able recently to show (Joyeux \& Baer, 1939). ${ }^{1}$

P. flaccida Meggitt, 1928 possesses a double crown of rostellar hooks. Its internal anatomy is however too briefly described to be recognizable, but we

1 Meggitt (1928) has inverted the figures 7 and 8 in his paper. The two different kinds of hooks deseribed for $P$. flaccida should be referred to fig. 8 whereas fig. 7, represents the hook of $P$. foetida. 
feel certain that this species will on subsequent examination be placed in the closely related genus Proterogynotaenia Fuhrmann, 1911.

$P$. jägerskiöldi Fuhrmann, 1909 can be easily distinguished by the shape and the number of the hooks, though the latter are somewhat longer than first indicated (Fuhrmann, 1909, p. 46), their length being $59 \mu$ instead of $52 \mu$; their number $29-34$.
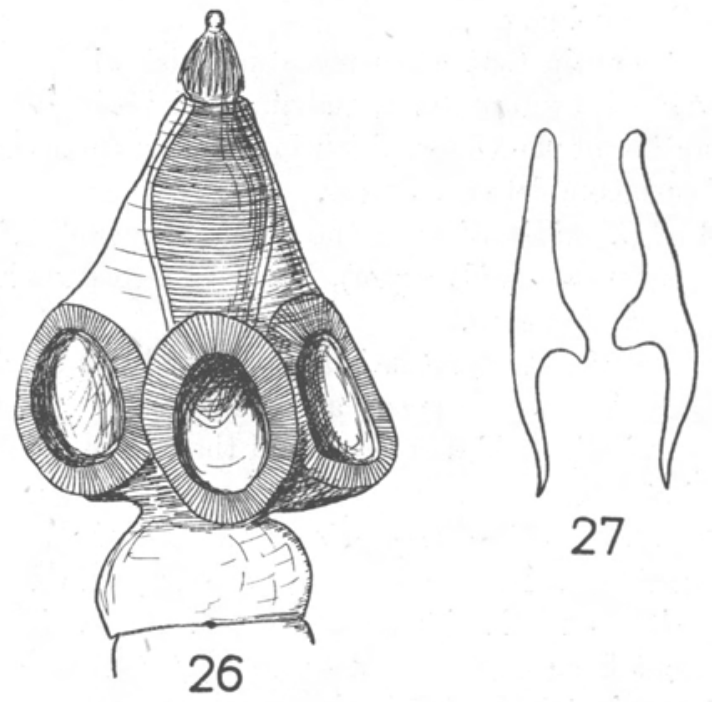

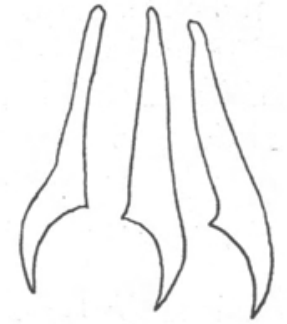

28

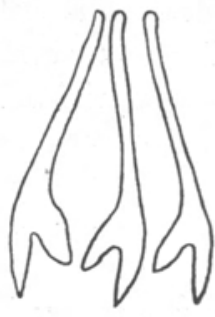

29

Figs. 26-29. 26. Progynotaenia evaginata Fuhrm. Scolex. 27. Hooks. 28. Progynotaenia odhneri Nyb. Hooks. 29. Progynotaenia jägerskiöldi Fuhrm. Hooks.

The genus Progynotaenia should therefore contain only three species viz.: P. evaginata Fuhrmann, 1909 syn. P. pauciannulata Baczynska, 1914 partim; P. odhneri Nybelin, 1914 syn. P. pauciannulata Baczynska, 1914 partim, P. foetida Meggitt, 1928; P. jägerskiöldi Fuhrmann, 1909. In this latter species, the uterus appears as a longitudinal sack with lateral outpocketings as in Proterogynotaenia rouxi Fuhrmann, 1911, and there is also a large receptaculum seminis. On the other hand, the cirrus pouch seems to pass ventrally to the longitudinal excretory vessels whereas in $P$. rouxi it passes between them. More and better preserved material must be studied to decide 
this point before eventually uniting these two genera or placing $P$. jägerskiöldi in the genus Proterogynotaenia. This would necessitate a complete revision of nomenclature as this species is also the type of the genus Progynotaenia.

In Figs. 27-29 we have drawn to the same scale the rostellar hooks of the three species belonging to the genus Progynotaenia so that they may be used for future reference.

The cestode family Acoleidae Fuhrmann, 1907 contains nine genera, six of which are tound exclusively in Charadriiform birds (Fuhrmann, 1932, p. 167). They all have in common the absence of a vaginal opening and moreover all trace of a vagina has disappeared. The musculature of the strobila is generally formed by two layers of longitudinal bundles separated by three layers of transverse fibres. In all the genera examined by us, the transverse excretory vessels pass dorsally to the female genitalia. These worms are usually protogynous or protandrous, there being a distinct tendency to a complete separation of the sexes which is finally reached in the genus Dioecocestus a genus restricted to grebes, though one species is found in an ibis. The genera Leptotaenia Cohn, 1901 and Gynandrotaenia Fuhrmann, 1936 are found in flamingos. The former is inadequately described from poorly preserved material and so cannot be placed definitely in this family.

In a recent paper Fuhrmann (1936) has divided the family Acoleidae into two distinct families, Acoleidae sens.str. and Progynotaeniidae Fuhrmann, 1936. Both of these families are in turn subdivided into Acoleinae Fuhrmann, 1900 with the genera Acoleus, Diplophallus, Gyrocoelia and Shipleyia, and Dioecocestinae Fuhrmann, 1936 containing the genus Dioecocestus. The family Progynotaeniidae is subdivided into Progynotaeniinae Fuhrmann, 1936, with the genera Progynotaenia, Proterogynotaenia and Leptotaenia, and Gynandrotaeniinae Fuhrmann, 1936, with the genus Gynandrotaenia.

Further research will show whether this method of classification is justifiable or not, especially as regards the establishment of a distinct family Progynotaeniidae.

Schistotaenia scolopendra (Diesing, 1850)

This species was collected from the gut of a pied-billed grebe, Podilymbus podiceps (L.). We will first redescribe this species before discussing its somewhat complicated history in the helminthological literature.

The length of our specimens is $7-11 \mathrm{~mm}$. and the greatest width $2 \mathrm{~mm}$. The scolex is large with a very powerfully built rostellum (Fig. 30), $440 \mu$ in diameter, and the oval suckers $280 \times 120 \mu$. The structure of the rostellum is very complicated, numerous layers of muscle fibres being present. It is $480 \mu$ long with a maximum diameter of $280 \mu$. The rostellar pouch is $560 \mu$ long and contains at its base two glandular masses staining a deep blue with hemalum. These glandular cells seem to open at the base of the rostellum, where the latter emerges from the scolex, although distinct ducts are not to be seen. 
The whole surface of the rostellum is beset with small spines and the apex bears a single crown of twenty very large hooks the shape of which is indicated in Fig. 36 . These hooks are 150-154 $\mu$ long with a base of $124 \mu$.

As several fragments of gut wall from the host are enclosed in the same tube as this material, we have been able to study the scolex in situ (Fig. 31).

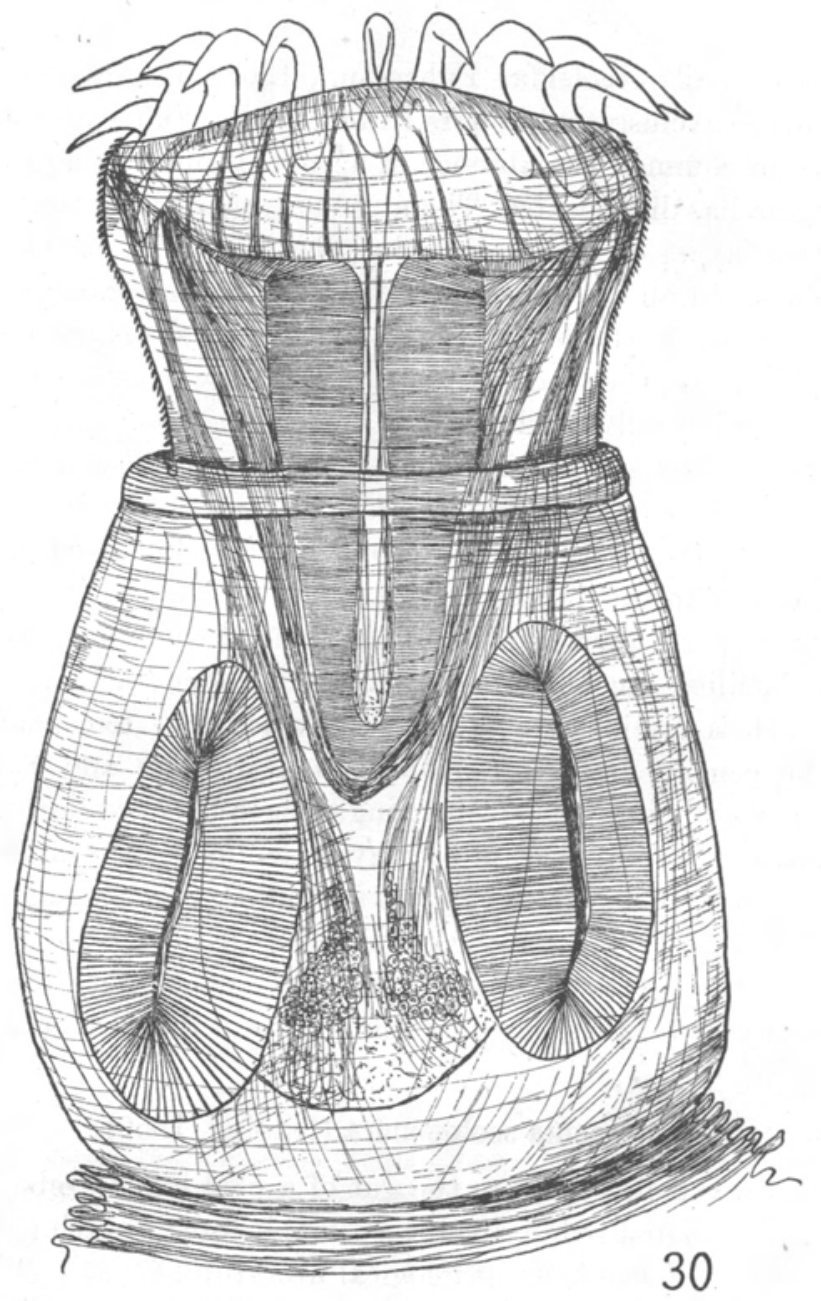

Fig. 30. Schistotaenia scolopendra (Dies.). Scolex.

It is deeply embedded in the mucosa, which is destroyed, as is also the muscularis mucosae, the anterior portion of the scolex bearing the hooks and the spines being in direct contact with the muscular wall of the gut. The hooks are embedded in the tissues of the host and necrosis occurs in the immediate vicinity of the scolex. 
The musculature of the strobila is very well developed, the longitudinal muscles forming two more or less distinct layers (Fig. 32), the bundles of the inner layer being larger than those of the outer one. Transverse muscle fibres are present though poorly developed, and numerous calcareous bodies are to be seen in the cortical parenchyma. The genital pores alternate irregularly and open laterally into the anterior quarter of the segment. There is a deep genital atrium and a vagina is of course absent. The cirrus pouch passes

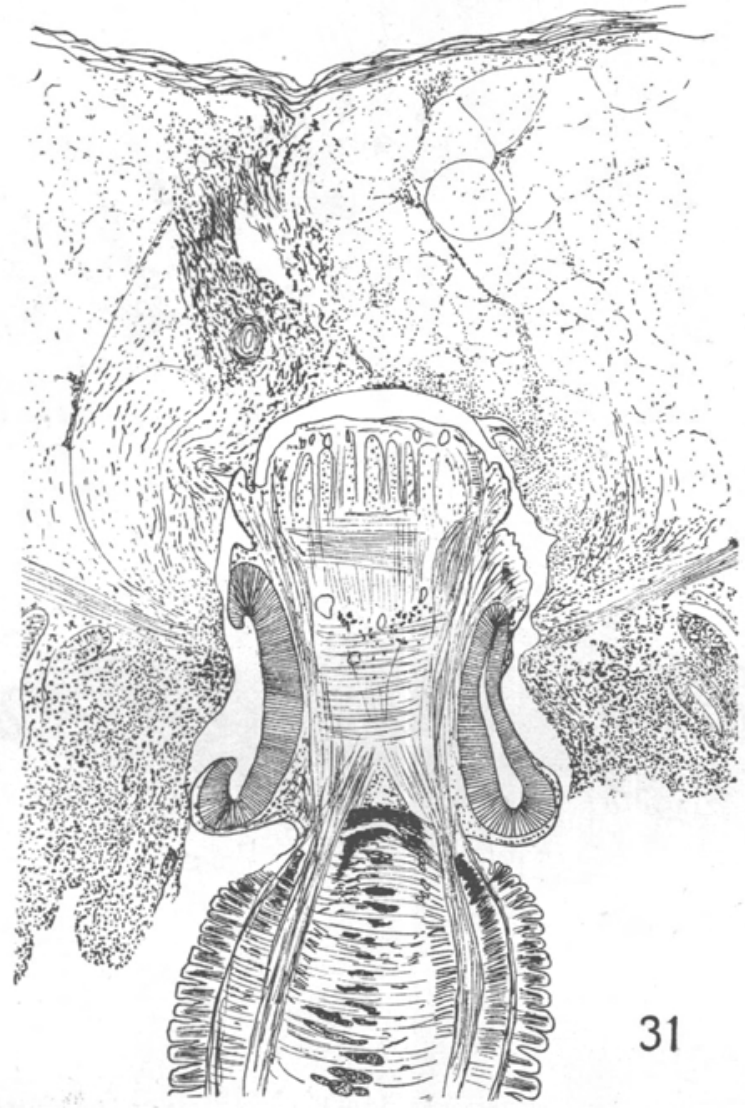

Fig. 31. Schistotaenia scolopendra (Dies.). Scolex embedded in the gut-wall of the host.

between the dorsal and ventral longitudinal excretory vessels; it is almost spherical, or pear-shaped, measuring $92-104 \mu$ in length with a maximum diameter of $74-81 \mu$. The wall of the pouch is thick and muscular and encloses a large cirrus densely beset with spines and small hooks. The available space left in the cirrus pouch is occupied entirely by coils of what one might consider as being the vas deferens, were it not for the two peculiar structures which precede the cirrus pouch and into which the vas deferens proper opens. These structures when examined in quite young segments can be easily distinguished from an ordinary vesicula seminis. 
The vas deferens proper enters an oval, glandular vesicle the walls of which contain several layers of glandular cells. This so-called prostatic gland is in communication, through a narrow duct, with a small, thin-walled cavity
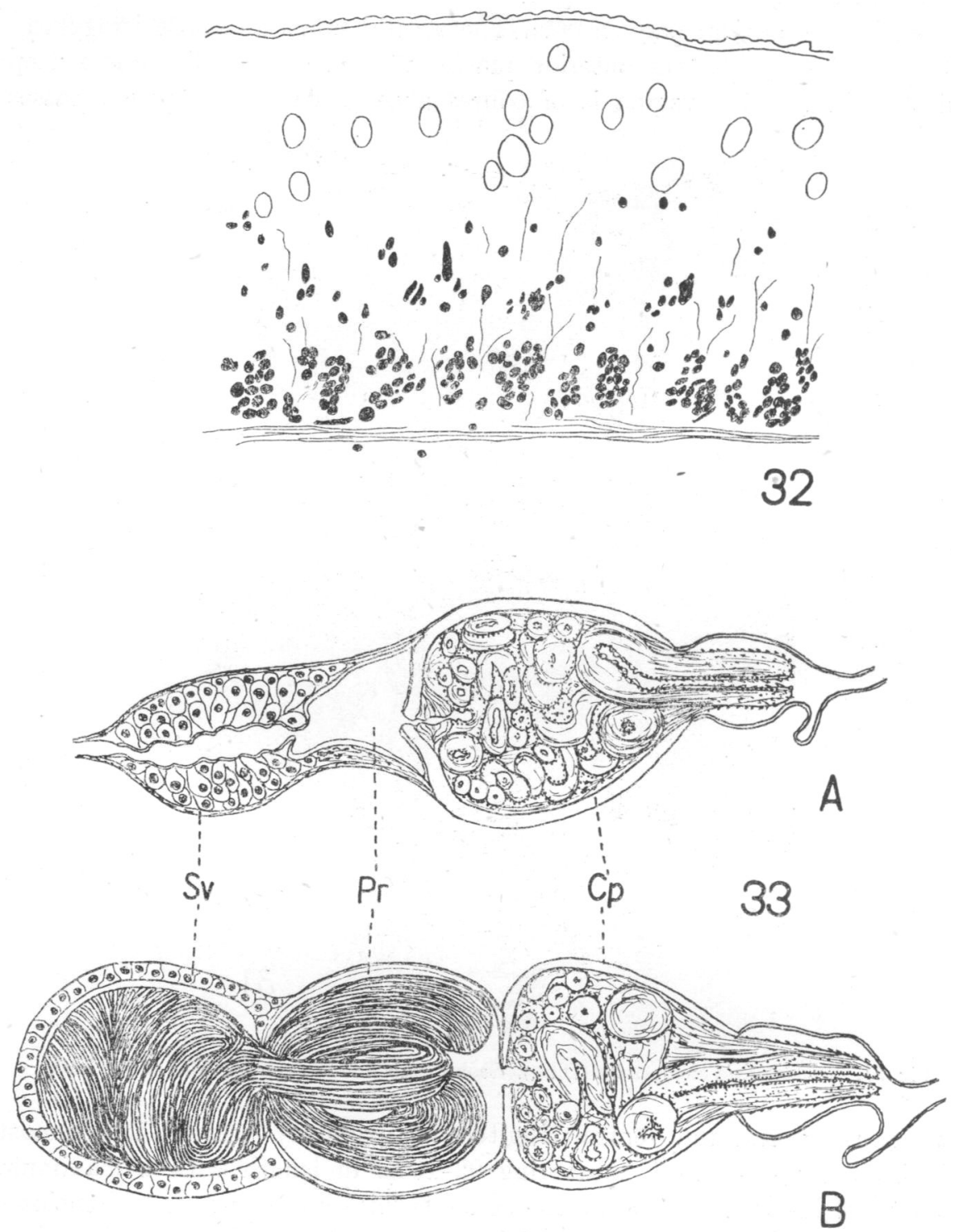

Figs. 32, 33. 32. Portion of a transverse section to show the musculature. 33. Cirrus pouch and accessory vesicles, $A$, in young segments, $B$, in older segments.

of a muscular nature which in turn opens into the cirrus pouch. This muscular cavity is no doubt an external seminal vesicle (Fig. 33A). In older segments, these two cavities are extremely distended with spermatozoa (Fig. 33B) so 
that the glandular wall of the prostata is no longer visible. A thin layer of muscular tissue surrounds the prostata and the seminal vesicle and attaches the latter to the cirrus pouch in such a way that one might be justified in considering these three structures as forming $\mathfrak{a}$ single cirrus pouch containing a prostata and a seminal vesicle. However, in very young segments it is possible to observe that the cirrus pouch proper is formed long before the other two structures appear; we must therefore consider these as modified portions of the vas deferens.

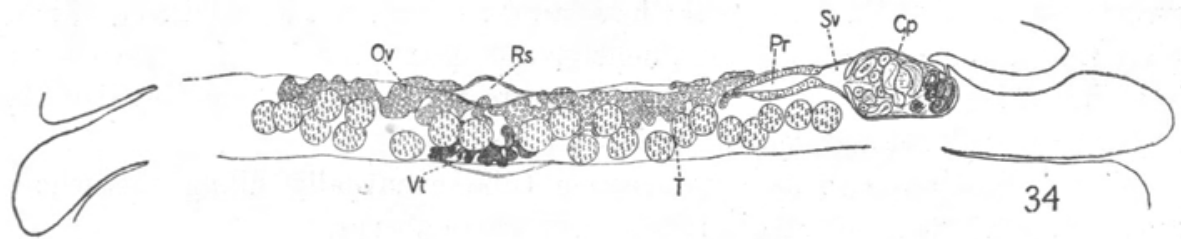

Fig. 34. Schistotaenia scolopendra (Dies.). Adult segment showing the anatomy: $C p$, cirrus pouch; $O v$, ovary; $P r$, prostata; $R s$, receptaculum seminis; $S v$, seminal vesicle; $T$, testes; $V t$, yolk gland.

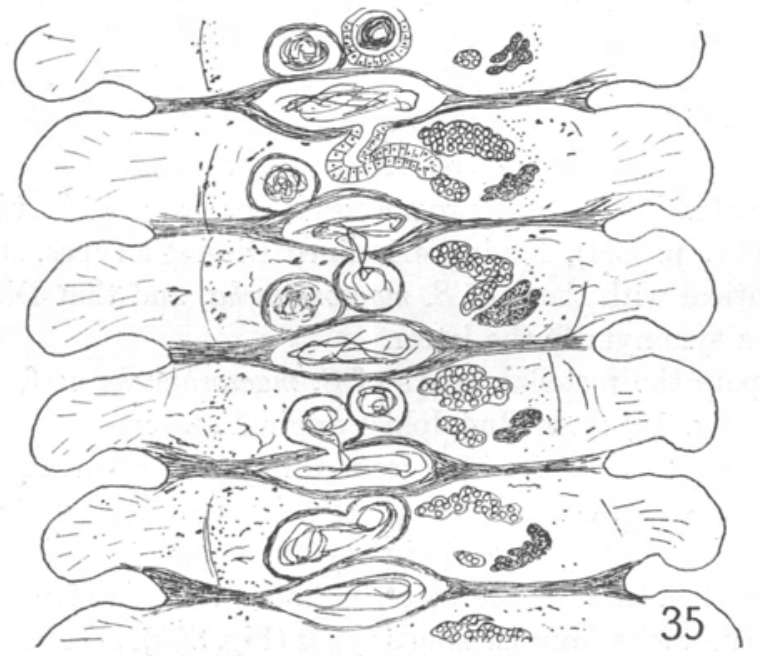

Fig. 35. Sagittal section passing through several segments showing the accessory vaginae and sections of the duct which unites them.

The testes are large but not very numerous; there are about 16-22 per segment, occupying the whole width (Fig. 34) in segments in which the female genitalia have begun to develop. They disappear very quickly in the subsequent proglottids. The ovary is distinctly lobed and occupies the ventral surface of the medulla. The yolk gland is also lobed and is found behind and dorsal to the ovary. The most interesting structure of the female genitalia is the receptaculum seminis. This latter appears early, before the female glands are clearly visible, as an ovoid sack situated at the anterior border of the segment in the mid-line. In sagittal sections (Fig. 35) it is seen that the wall of the 
receptaculum is continuous with two strands of fibrous tissue ending beneath the cuticula of the dorsal and ventral surfaces of the worm. Definite ducts are not visible, they may however first appear in gravid segments only; unfortunately such segments are not yet developed in our specimens. The receptacula communicate with one another from one segment to the next, through a thin-walled duct which joins them. From this duct or in its immediate vicinity arises a thick-walled tube which opens into the oviduct. If we were to consider this thick-walled tube as the true receptaculum seminis, the structures described above would have to be considered as vaginae, which, physiologically, they are. Consequently, the spermatozoa which have been introduced into one of these vaginae migrate throughout the entire strobila as in the closely related genus Tatria.

The uterus appears as a transverse tube eventually filling the whole segment. Unfortunately, fully ripe segments are absent.

Schistotaenia scolopendra was described for the first time by Diesing (1856, p. 35), who gave no drawings of the hooks. Diesing's original material, from Podicipes dominicus (L.), a South American species of grebe, was re-examined by Cohn (1900) who, however, also refrained from describing the shape of the rostellar hooks. Cohn $(1900$, p. 276) doubtfully considered this species to be distinct from Schistotaenia macrorhyncha (Rudolphi, 1810) from old World grebes. Clerc (1907, p. 708), redescribing the anatomy of S. macrorhyncha, states that the identity of these two species is not proved. On the other hand, Fuhrmann (1907, p. 534), having examined Diesing's types, states that the hooks are identical with those of $S$. macrorhyncha, and that Diesing's species must lapse as a synonym of the latter.

If we compare the rostellar hooks of $S$. macrorhyncha as figured by Cohn (1900, pl. XV, fig. 16) from Rudolphi's original specimens and those drawn by Krabbe (1869, pl. VII, fig. 172) from European grebes with the rostellar hooks of $S$. scolopendra, we find that there exists a distinct difference between them which is especially noticeable in the shape and the width of the blade (Fig. 36). That the shape of the rostellar hooks is variable is proved by our drawings of these hooks from Diesing's types (Fig. 36b), specimens from Brazil (Fig. 36c) and from our present specimens (Fig. 36d). Moreover the measurements are the following: Diesing's type, length $161 \mu$, base $133 \mu$; Brazilian specimens, length $177 \mu$, base $150 \mu$; specimens from Antigua, length $150-154 \mu$, base $124 \mu$. The range of variation would thus appear to be for the length $150-177 \mu$ and for the base $124-150 \mu$.

For $S$. macrorhyncha, Wedl (1856, p. 18) indicates the length of the hook as $148 \mu$ and Krabbe $(1869$, p. 305) as $150 \mu$. We have found in a South African grebe, Podiceps capensis Bp., a species which we refer, on account of the shape of the hooks, to Schistotaenia macrorhyncha, and in which the hooks measure $162 \mu$ in length with a base of $158 \mu$.

If in all these measurements we take the difference in the length of the hook and the length of the base, we find that this is 4 in our Cape specimens, 
and in Cohn's and Krabbe's drawings of S. macrorhyncha, 5. On the other hand, in the specimens which we refer to $S$. scolopendra, this difference varies from 26 to 28 . This is therefore another way of expressing the difference in shape of the rostellar hooks of these two species.

If we compare the muscular system of these two species, we find that in $S$. macrorhyncha the longitudinal muscles are more powerfully developed than in S. scolopendra (compare Figs. 32 and 37). The cirrus pouch in S. macrorhyncha is larger, measuring $144-158 \mu$ in length and $108-115 \mu$ in diameter. When the cirrus is fully everted, the pouch measures $152 \times 127 \mu$. The testes are also more numerous, their number being 38-40 per segment.

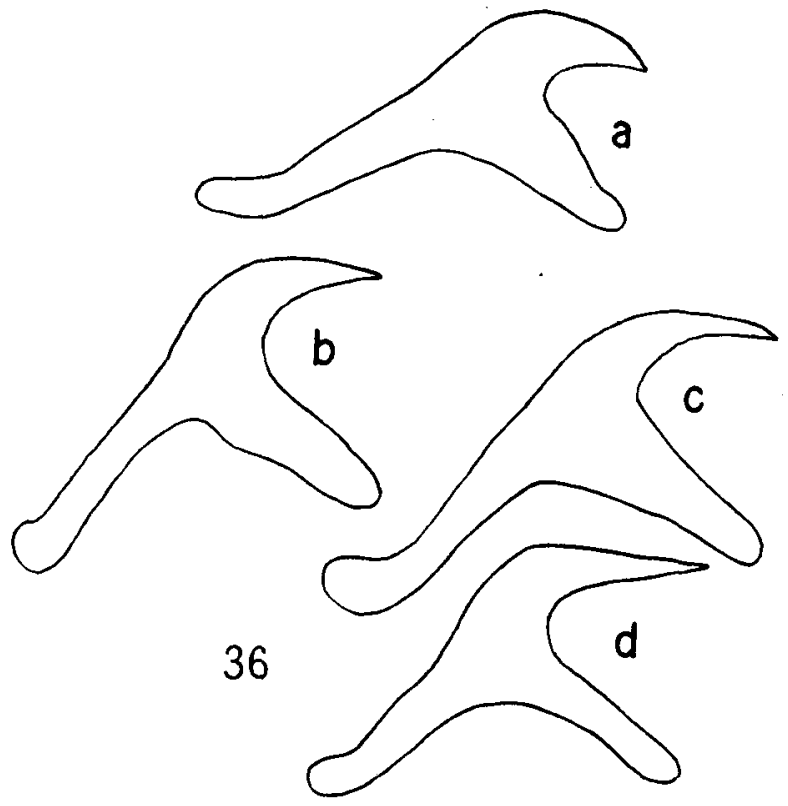

Fig. 36. a, Schistotaenia macrorhyncha (Rud.), rostellar hook; b-d, Schistotaenia scolopendra (Dies.), rostellar hooks; $b$, from Diesing's types; $c$, from Brazilian material; $d$, present material.

On the other hand, in S. macrorhyncha, the dorsal and ventral secondary vaginal openings are fully formed in young segments: this peculiarity may perhaps also be useful in distinguishing the two species.

We therefore come to the conclusion that $S$. scolopendra (Diesing, 1850) from New World grebes is a valid species and should be considered as distinct from $S$. macrorhyncha from Old World grebes.

A close examination of these two species has revealed the fact that the receptacula seminis communicate with one another in the consecutive segments. This latter anatomical detail has never before been observed in the genus Schistotaenia and seems to denote its very close relationship to the genus Tatria Kowalewski, 1904, a genus also found exclusively in grebes. It would have been useful if a revision of the species of this latter genus could have 
been undertaken. The different types are, however, too poorly preserved and too fragmentary to warrant accurate descriptions. The anatomy of these two genera is almost identical, namely the structure of the cirrus pouch with the two accessory vesicles. The testes are also large though generally fewer in the genus Tatria. The greatly elongated lateral borders of the segments are also found in Schistotaenia. It is most likely that these two genera will have to be united later on, but such a measure is still premature, until more and better preserved material has been examined.

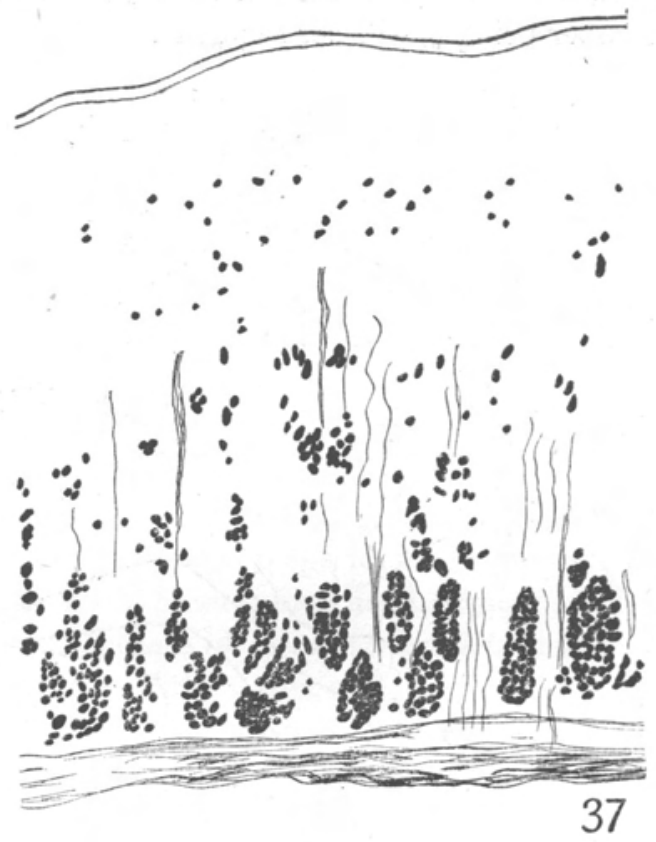

Fig. 37. Schistotaenia macrorhymcha (Rud.). Portion of a transverse section to show the longitudinal musculature.

In the present paper we have intentionally left out the minor details which can be found in the original descriptions, in order to give only the facts. We wish, however, to stress the importance of examining the type material before undertaking a revision. It is important that new species should be described from well-preserved specimens. Helminthological literature is far too congested to leave room for more inadequate descriptions. Too many former results have been taken for granted when establishing new species and it will be necessary in the future to re-examine all the types of a genus before describing new species or undertaking a revision of the existing ones. The present classification of the Cestoda is coherent and as natural as any classification can ever hope to be, yet the internal status of many genera is chaotic and the identity of the species too uncertain. 


\section{REFERENCES}

Clausen, E. (1915). Recherches anatomiques et histologiques sur quelques Cestodes d'Oiseaux. Thesis Neuchâtel, 111 pp., 51 figs.

Clkrc, W. (1907). Notes sur les Cestodes d'Oiseaux de l'Oural, III. Zbl. Bakt. Orig. 43, 703-8, 2 pls.

CoHN, L. (1900). Zur Anatomie der Vogelcestoden, I. Z. wiss. Zool. 67, 255-90, pls. XIV-XV.

Drrsing, K. M. (1856). Zwanzig Arten von Cephalocotyleen. S.B. Akad. Wiss. Wien, math. nat. 12, 23-8, 6 pls.

Furrmann, O. (1899). Mitteilungen über Vogeltaenien. Zbl. Balkt. Orig. 26, 618-22, figs. 1-3.

— (1899a). Deux singuliers Ténias d'Oiseaux. Rev. suisse Zool. 7, 341-51, pl. XVII.

- (1900). Zur Kenntnis der Acoleinae. Zbl. Bakt. Orig. 28, 363-76, 12 -figs.

___ (1907). Bekannte und neue Arten von Vogeltaenien. Zbl. Bakt. Orig. 45, 516-36, 43 figs.

- (1908). Nouveaux Ténias d'Oiseaux. Rev. suisse Zool. 16, 27-73, 60 figs.

- (1921). Die Cestoden der Deutschen Südpolar-Expedition 1901-1903. Deutsche Südpolar-Expedition, 16, 469-524.

- (1932). Les Ténias d'Oiseaux. Mém. Univ. Neuchâtel, 8, 381 pp.

- (1936). Un singulier Ténia d'Oiseaux, Gynandrotaenia stammeri n.g., n.sp. Ann. Parasit. 14, 261-71, 11 figs.

Jomnston, T. H. (1912). On a re-examination of the types of Krefft's species of Cestoda. Rec. Austr. Mus. 9, 1-35, pls. XV-XVI.

JoykUX, Ch. \& Bater, J. G. (1939). Sur quelques Cestodes des Charadriiformes. Bull. Soc. Zool. Fr. 64, 171-86, 4 figs.

KrabBe, H. (1869). Bidrag til Kundskab om Fuglenes Baendelorme. Dansk Vid. Selsk. Skr. naturvid. math. 8, 249-363, 10 pls.

Lenton, E. (1927). Notes on Cestode parasites of Birds. Proc. U.S. Nat. Mus. 70, 1-75, pls. I-XV.

Maplastone, P. A. \& Sodthwert, T. (1922). Notes on Australian Cestodes. IV. Ann. Trop. Med. Parasit. 16, 61-8, 7 figs.

MAYHEW, R. L. (1925). Studies on the avian species of the Cestode family Hymenolepididae. Ill. Biol. Monogr. 10, 1-125, pls. I-X.

Megarit, F. J. (1928). Report on a collection of Cestoda mainly from Egypt. Part III. Parasitol. 20, 315-28, pl. XIX.

OrtLkpp, R. J. (1937). South African Helminths. Part I. Onderstepoort J. Vet. Sci. Anim. Ind. 9, 311-36, 21 figs.

SkRdarin, K. J. (1914). Beitrag zur Kenntnis einiger Vogelcestoden. Zbl. Bakt. Orig. 75, 59-83, 42 figs.

Tseng Shen (1933). Studies on avian Cestodes from China. Part II. Parasitology, 24, 500-11, figs. 38-54.

WEDL, C. (1856). Charakteristik mehrerer grösstenteils neuer Taenien. S.B. Akad. Wiss. Wien, Math. Naturw. 18, 5-27, 3 pls.

(MS. received for publication 28. xI. 1939.—Ed.) 